\title{
Mammographically and MRI occult breast cancer
}

\author{
Sherif Monib, Emre Pakdemirli, Kelvin Chong
}

St Albans Breast Unit, West Hertfordshire Hospitals NHS Trust, St Albans, UK

\section{Correspondence to}

Mr Sherif Monib,

sherif.monib@nhs.net

Accepted 6 June 2019

\section{DESCRIPTION}

We are presenting the case of a 64-years-old woman who had normal bilateral mammogram 1 year prior to presenting with a palpable $30 \mathrm{~mm} \mathrm{left}$ breast lump which was this time neither seen on mammogram (figure 1) or breast MRI (figure 2), only vaguely seen (under sized $20 \mathrm{~mm}$ ) on breast ultrasound scan (figure 3 ).

Postoperative histology revealed $37.5 \mathrm{~mm}$ invasive duct carcinoma grade II estrogen receptor, progesterone receptor positive, Her2 negative; sentinel lymph node biopsy was negative.

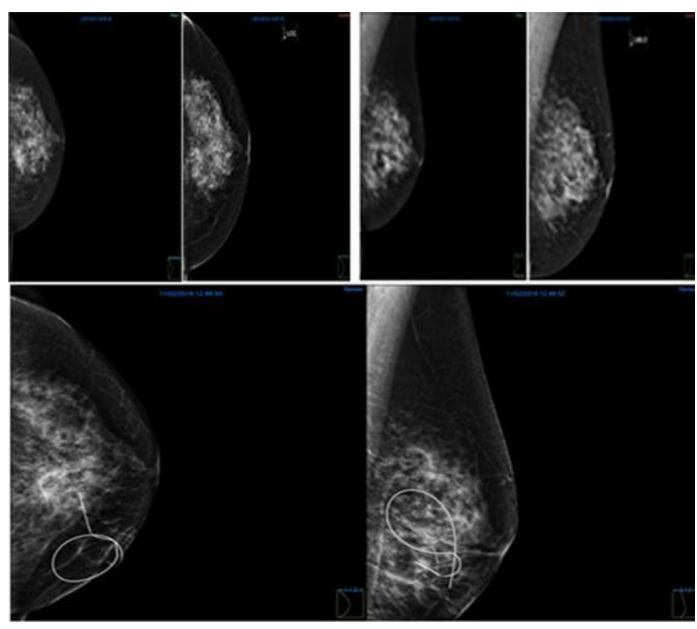

Figure 1 Cranio-caudal (CC) and medio-lateral-oblique (MLO) screening mammograms of 2017 (right) and 2018 (left) did not reveal any suspecious lesion, post guide wire mammograms: CC (right) and MLO (left). The barb of the wire is in close relation to the post-biopsy clip.

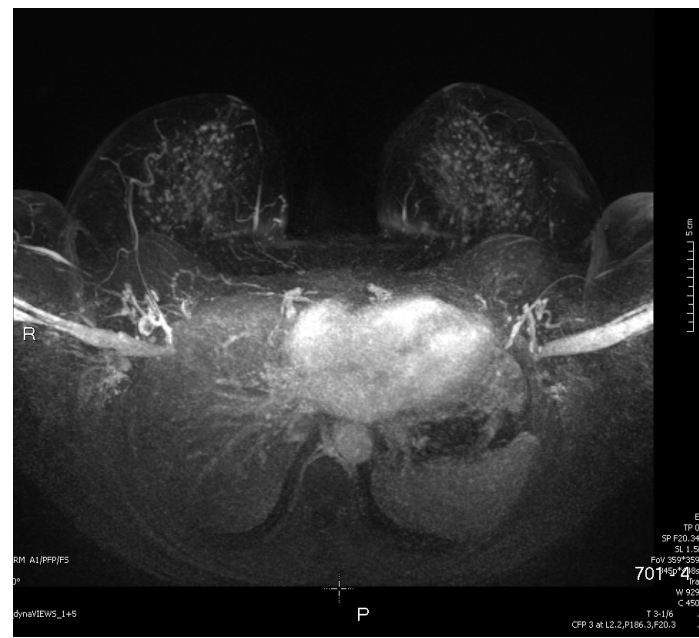

Figure 2 Breast MRI: MRI maximum intensity projection image. Bilateral nodular breasts, but mass lesion in left breast cannot be appreciated.

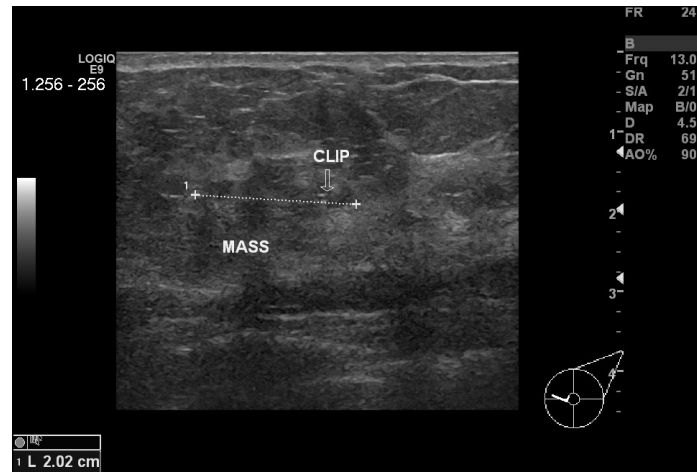

Figure 3 Left breast ultrasound scan: left breast medial aspect vague but visible hypoechoic $20 \mathrm{~mm}$ sized mass containing post-biopsy clip.

\section{Learning points}

- Breast cancer can be occult on both mammogram and MRI.

- We strongly believe that a breast ultrasound scan must be done for any patient presenting with breast lump who has a normal mammogram.

Mammographically occult breast cancer is a wellknown entity; recent studies have shown that MRI cannot be used as a single imaging modality for the evaluation of breast cancer, as false negative results can occur. ${ }^{1}$

Various histological subtypes of breast cancer have been described as sometimes presenting with non-enhancement or late enhancement on breast MRI. These include lobular, mucinous and tubular cancers. ${ }^{2}$

We believe that this is the first case in literature who is both mammographically and MRI occult also with a very common histology which is not known to be occult on mammogram or MRI.

Contributors SM contributed in patient's management, literature review as well as manuscript editing. EP contributed in patient's management and manuscript editing. KC contributed in patient's management. All authors read and approved the manuscript.

Funding The authors have not declared a specific grant for this research from any funding agency in the public, commercial or not-for-profit sectors.

Competing interests None declared.

Patient consent for publication Obtained.

Provenance and peer review Not commissioned; externally peer reviewed.

\section{REFERENCES}

1 Maxwell AJ, Lim YY, Hurley E, et al. False-negative MRI breast screening in high-risk women. Clin Radiol 2017;72:207-16.

2 Kuhl CK, Schild HH. Dynamic image interpretation of MRI of the breast. J Magn Reson Imaging 2000;12:965-74. 
Images in...

Copyright 2019 BMJ Publishing Group. All rights reserved. For permission to reuse any of this content visit https://www.bmj.com/company/products-services/rights-and-licensing/permissions/

BMJ Case Report Fellows may re-use this article for personal use and teaching without any further permission.

Become a Fellow of BMJ Case Reports today and you can:

- Submit as many cases as you like

- Enjoy fast sympathetic peer review and rapid publication of accepted articles

Access all the published articles

Re-use any of the published material for personal use and teaching without further permission

Customer Service

If you have any further queries about your subscription, please contact our customer services team on +44 (0) 2071111105 or via email at support@bmj.com.

Visit casereports.bmj.com for more articles like this and to become a Fellow 